\title{
EL DESAFÍO DEL MIRAMAMOLÍN ANTES DE LA BATALLA DE LAS NAVAS DE TOLOSA (1212). FUENTES, DATACIÓN Y POSIBLES ORÍGENES
}

\author{
MARTín Alvira CABRER \\ Universidad Complutense de Madrid
}

La batalla de Las Navas de Tolosa (16 de julio de 1212) ${ }^{1}$ fue un acontecimiento de dimensiones excepcionales, cuyo eco llegó a numerosas crónicas y anales de todo el Occidente europeo ${ }^{2}$. Buena parte de estas fuentes aseguran que, en los orígenes de este choque, el Miramamolín almohade alNāṣir (1199-1213) había proclamado su deseo de combatir a toda la cristiandad en una gran batalla. Pese a su coincidencia y difusión, el «desafío del Miramamolín» no consta en ninguna fuente musulmana conocida ni en fuentes cristianas tan importantes como la Historia de rebus Hispaniae del arzobispo de Toledo Rodrigo Jiménez de Rada (1243) o las cartas de Alfon-

\footnotetext{
' Este trabajo y otros citados de mi autoría forman parte del proyecto de investigación de la DGICYT, titulado «La guerra en la Edad Media Hispánica: implicaciones materiales y mentales» (N. ${ }^{\circ}$ PB93-0018), bajo la dirección de don Emilio Mitre Fernández, catedrático de Historia Medieval de la Universidad Complutense de Madrid.

${ }^{2}$ Sobre la batalla de Las Navas de Tolosa, véase Huici Miranda, A., Estudio sobre la batalla de Las Navas de Tolosa, Valencia, 1916; id., Las grandes batallas de la reconquista durante las invasiones africanas (almorávides, almohades, benimerines), Madrid, 219-327, Goñi Gaztambide, J., Historia de la bula de cruzada en España, Vitoria, 1958, 110-132; González, J., El reino de Castilla en época de Alfonso VIII, 3 vols., Madrid, 1960, vol. I, pp. 981 y ss.; Eslava Galán, J., «Tácticas en la batalla de Las Navas de Tolosa», Cuadernos de Estudios Medievales, VI-VII (1978-79), 39-53; Ruiz Doménec, J. E., «El significado histórico de la batalla de Las Navas de Tolosa y sus consecuencias», Historia General de España y América, vol. IV («La España de los cinco reinos»), Madrid, 1984, 585-589; Martínez Díez, G., Alfonso VIII, rey de Castilla y Toledo, «Col. Corona de España», XXI, «Series Reyes de León y Castilla», Burgos, 1995, 175-213. Sobre los aspectos litúrgicos e ideológicomentales, véase Alvira Cabrer, M., «Dimensiones religiosas y liturgia de la batalla plenomedieval: Las Navas de Tolosa, 16 de julio de 1212», XX Siglos, núm. 19 (Madrid, 1994), 33-46; id., «La muerte del enemigo en el Pleno Medievo: cifras e ideología (el modelo de Las Navas de Tolosa)», Hispania, LV/190 (1995), 403-424. Para las repercusiones de esta batalla en Europa, véanse los apéndices documentales en los trabajos de Huici y la recopilación de fuentes europeas realizada por D. W. Lomax en «La conquista de Andalucía a través de la historiografía europea de la época», Andalucía entre Oriente y Occidente (1236-1492), Actas del V Coloquio Internacional de Historia Medieval de Andalucía, Córdoba, 1986, 39-41, notas $15-23$.
} 
so VIII de Castilla (1158-1214) y de sus hijas Berenguela de León y Blanca de Castilla ${ }^{3}$.

Dejando de lado las interesantes referencias ideológico-mentales de este legendario episodio, analizaremos su aparición en las fuentes europeas del siglo XIII, la evolución de sus versiones y cuándo, cómo y por qué se convirtió en uno de los más originales elementos de la Cruzada de 1212 y del recuerdo histórico de la batalla de Las Navas de Tolosa ${ }^{4}$.

\section{EL «DESAFío DEL MiRAMAMOLín» EN LAS FUENTES DEL SIGLO XIII:} LAS VERSIONES

El «desafío de Miramamolín» no aparece en todas las fuentes que informan de la batalla de 1212 y posee diferentes versiones.

\section{La batalla contra «todos los adoradores de la cruz»}

Cronológicamente, la primera noticia cierta del «desafío del Miramamolín» aparece en la carta que el papa Inocencio III (1198-1216) envió a los arzobispos de Toledo y Santiago el 5 de abril de 1212 ordenándoles mantener la paz entre los reyes cristianos durante la futura campaña: quin eciam mutuum auxilium sibi prestent adversas crucis dominice inimicos, qui non solum ad destructionem Hyspaniarum aspirant, verum etiam in aliis fidelium Christi terris comminantur suam serviciam exercere ac nomen, quod absit si possint, opprimere christianum ${ }^{5}$.

\footnotetext{
${ }^{3}$ Huici, Las grandes batallas, 249; Rodrigo Jiménez de Rada, Historia de los hechos de España, ed. española de J. Fernández Valverde, Madrid, 1989; Carta de Alfonso VIII en González, III, núm. 897, 566-572; Gaspar Ibáñez de Segovia Peralta y Mendoza, marqués de Mondéjar, Memorias históricas de la vida y acciones del rey don Alonso el Noble, octavo de este nombre, Madrid, 1783, ap. XCVIII, y Huici, Estudio, fuentes cristianas, ap. II, 166-170; Carta de la reina Bereng 'ela en González, III, núm. 898, 572-574, y Recueil des Historiens des Gaules et de la France, t. XIX (París, 1880), 254-255; Carta de la princesa Blanca en Recueil, XIX (París, 1880), 255-256.

${ }^{4}$ Véase una aproximación a esta cuestión en Alvira Cabrer, M., «La concepción de la batalla como duelo y la propaganda de cruzada a principios del siglo XIII: el desafío del Miramamolín a la cristiandad antes de la batalla de Las Navas de Tolosa (16 de julio de 1212), Heresis, 26 (1996), 1-19. Se han consultado todas las fuentes europeas mencionadas por el profesor Lomax en su artículo, salvo algunas crónicas de monasterios británicos (Tewkesbury, Winchester, Worcester, Strata Florida y Barnwell) a las que nos hemos podido acceder.

5 Mansilla, D., «La documentación pontificia de Inocencio III (1198-1216)», Monumenta Hispaniae Vaticana, t. I, Roma, 1955, núm. 471, 502.
} 
Arnaldo Amalarico (h. 1196-1225), legado de la Cruzada Albigense y arzobispo de Narbona, lo refiere en la carta que escribió al Capítulo General del Císter narrando la batalla de Las Navas de Tolosa, en la que había participado: Os anunciamos una nueva de gran alegría, porque el Miramamolín, rey de Marruecos, que, según hemos oído a muchos, había declarado la guerra a todos los que adoran la Cruz, ha sido vencido y puesto en fuga en batalla campal por los adoradores de la Cruz ${ }^{6}$.

Este auténtico «parte de guerra» fue escrito poco después de la batalla, siendo válida la fecha de redacción que ofrecen los anales de la abadía cisterciense de Waverley (Surrey-Inglaterra): Datum Tholeti Sabbato ante assumptionem beatae Virginis Mariae, esto es, el sábado 11 de agosto de $1212^{7}$. La carta del venerable Arnaldo fue leída el 13 de septiembre de ese año ante unos trescientos abades de toda Europa y Tierra Santa que formaban el Capítulo General del Císter, lo que explica que la noticia del «desafío» se difundiera notablemente desde entonces ${ }^{8}$.

Entre los cronistas hispanos, el «desafío del Miramamolín» es constatado por el prelado autor de la Crónica Latina de los Reyes de Castilla (h. 1236): Audito namque quod rex gloriosus miserat archiepiscopum Toletanum et legatos suois in Franciam et in alias regiones Christianorum inuitare populum catolice fidei sectatorem ad bellum futurum, fertur dixisse rex Marroquitanus quia ipse potens erat bellare contra omnes qui signum Crucis adorabant ${ }^{9}$.

Lo mismo asegura el obispo leonés Lucas de Tuy en su Chronicon Mundi (h. 1236): Rex Miramamolinis, ut haec audivit [la organización de la cruzada], valde pertimuit, et doluit se verbum superbiae protulisse, scilicet quod vinceret in campo omnes adorantes crucem Christi ${ }^{10}$.

${ }^{6}$ Huici, Estudio, fuentes cristianas, ap. III, 170; Mondéjar, ap. CIII, y Recueil, XIX, 250255. Sobre este protagonista de la campaña de 1212, véase Foreville, R., «Arnaud Amalric, Archevêque de Narbonne (1196-1225)», Gouvernement et vie de l'Eglise au Moyen-Age. Recueil d'études, Londres, 1979, 129-146, y Alvira Cabrer, M., «El venerable Arnaldo Amalarico (h. 1196-1225). Idea y realidad de un cisterciense entre dos cruzadas», Hispania Sacra, 48 (1996), 569-591.

7 Annales Waverleienses, en Rerum Anglicarum Scriptores, vol. II (Osoney, 1687), p. 175

${ }^{8}$ Buen ejemplo de ello son los citados Annales Waverleienses: Divulgatum est per Angliam quod Miramamelinus Rex Marrochenensis cum magna multitudine, \& fortitudine (qui sicut audivimus a plerique, bellum indixerat omnibus illis qui crucem adorant) ab illis eisdem qui crucem colunt bello campestri devictus est, \& fugatus, op. cit., II, 175, y Recueil, XVIII (París, 1879), 199-200. La carta de Arnaldo Amalarico también sirvió de fuente a los anales de la abadía benedictina de Margam (Gales), en Rerum Anglicarum Scriptores, vol. II, p. 15, y a la crónica de Salimbene de Adam, en Monumenta Germaniae Historica, Scriptores, vol. XXXII (Hanover, 1905-1913), p. 28.

${ }^{9}$ Crónica Latina de los Reyes de Castilla, ed. L. Charlo Brea, Cádiz, 1984, p. 32, líneas 5-10.

${ }^{10}$ Lucas de Tuy, Crónica de España, ed. J. Puyol, Madrid, RAH, 1926, lib. IV, cap. LXXXIII, p. 414 
$\mathrm{Y}$ de forma similar se expresan los Anales Toledanos I: e este perdó [la cruzada] fue porque el rey de Marruecos dixo que lidiaría con quantos adoraban Cruz en todo el mundo ${ }^{11}$.

Las fuentes francesas también se hicieron eco del «desafío». Guillermo el Bretón, cronista del rey Felipe Augusto de Francia (1137-1226), asegura en su Crónica (h. 1223): Eodem anno [1212, aunque dice 1211] Rex quidam Sarracenos qui dicebatur Mummilinus, quod lingua eorum sonat Regum Rex, collecto exercito infinito paganorum, agressus fines Hispaniae, locutus est in magna superbia contra christianos, et obtulit eis bellum ${ }^{12}$.

Las Grandes Crónicas de St. Dénis de París siguen esta fuente: En cele année vint eu roiaume d'Espagne uns Rois Sarrazin qui avoit nom Mommelins; si vaut autant en leur langue come Rois des rois. Si grany ost amena, que la multitude de sa gent senbloit estre sanz nombre, en si grant orguel parla contre les crestiens et la menaça forment... ${ }^{13}$.

El cisterciense Alberico, abad de Nôtre-Dame de Trois-Fontaines, repite la misma noticia en su Chronica (h. 1241): Anno eodem expeditionis infantium rex Sarracenorum in Hispania, qui dicebatur Mammelinis, agressus fines Hispaniensium christianorum et locutus est in magna superbia contra christicolas et optulit eis bellum ${ }^{14}$.

Finalmente, el tardío trovador Guilhem Aneliers de Tolosa también recoge el mismo dato en su poema sobre la guerra de Navarra (h. 1277): $E$ el temps qu'él regnaba [Sancho VII de Navarra (1194-1234)], lay vas Ubeda fó / Un rey Almomenin molt mal e molt feló, / E per l'erguill qu'avia fi cridar abandó / a totz cels qu'en la Vergen e en la Croz credió / Que les daría batailla al iorn qu'ils voldrió ${ }^{15}$.

Interesa señalar, en primer lugar, que estas fuentes — salvo la aséptica documentación pontificia — indican que la noticia sobre el «desafío» del ca-

"Anales Toledanos I; Huici, Estudio, fuentes cristianas, ap. IV, 177.

12 Guillelmes Armorico Gesta Philippi Augusti Francorum Regis, Recueil, XVII (París, 1878), 85-86; ed. H. F. Delaborde, Chronique, Oeuvres de Rigord et de Guillaume le Breton, historiens de Philippe Auguste, París, 1885, p. 241, citado en francés por Berlioz, J., «Tuez-les tous, Dieu reconnaîtra les siens». La croisade contre les Albigeois vue par Césaire de Heisterbach, Portet-sur-Garonne, 1994, p. 57.

${ }_{13}$ Recueil, XVII (París, 1878), 398.

14 Chronica Albrici monachi Trium Fontium, M. G. H. SS., (Hanover, 1874), 894; trad. Huici, Estudio, fuentes cristianas, apart. VI, 181, y Mondéjar, ap. CXXII.

${ }_{15} Y$ en el tiempo en que él reinaba hubo en Ubeda un rey Almumenín muy malo y muy felón, y por su soberbia anunció que a todos los que creían en la Virgen y en la Cruz les presentaría batalla el día que quisieran; Guillermo Aneliers de Tolosa, La guerra civil de Pamplona, ed. P. Ilarregui, Pamplona, 1847, p. 31; traducción en Mongelos, R. J., «Los primeros cantores de Las Navas», Boletín de la Comisión de Monumentos Históricos y Artísticos de Navarra, $11-12$ (1912), 78-79. 
lifa almohade tuvo un origen no escrito. El arzobispo de Narbona, la Crónica Latina y Lucas de Tuy hacen constar que se trata de algo que han oído, mientras que el resto no alude a un origen concreto.

\section{La destrucción de España y Europa. La conquista de Roma}

Otras fuentes ofrecen versiones aún más complejas del «desafío del Miramamolín» al añadir a estos datos el deseo musulmán de ocupar y destruir España o la cristiandad hispana.

Si bien esto se insinuaba ya en la carta de Inocencio III, también tiene reflejo en otras fuentes europeas relativas a Las Navas. Así, la crónica de la iglesia de San Marcial de Limoges (dep. Haute-Vienne) habla de la Península Ibérica como escenario del ataque musulmán: [1211] una multitud innumerable de sarracenos ha venido a España para ahuyentar y oprimir a la cristiandad $^{16}$.

También el cronicón de la iglesia de Santo Domingo el Menor de Lieja (Bélgica) da cuenta del fin último de la invasión almohade: [1212] Mensee julii, gratia Dei, innumerabilis turba Sarracenorum, quar convenerat ad Hispaniam occupandam ${ }^{17}$.

La crónica del monasterio benedictino de San Salvador de Andrés (dep. Pas-de-Calais) coincide con esta noticia (h. 1234): Anno Domini 1212. Rex de Marroc, id es Kartaginensis, totam christianitatem Hispaniae molitur debellare... ${ }^{18}$.

La invasión musulmana que precedió a la campaña de 1212 alcanza en otras fuentes carácter de auténtica amenaza colectiva. Así ocurre en la crónica de Sicardo, obispo de Cremona (h. 1222), y en la Chronica Imperatorum de Alberto Milioli de Reggio (h. 1256), que copia al cremonense: Eodem anno, scilicet MCCXII, Almiramomelin rex Mauritanie veniens in Yspaniam cum infinita multitudine Sarracenorum minitabatur non solum Yspaniam, set et Romam immo Europam capere universam ${ }^{19}$. También

${ }^{16}$ Ex chronico Bernardi Iterii monachi et armarii Sancti Martialis Lemovicensis, en Recueil, XVIII (París, 1879), 229-230, citado y traducido por Lomax, 40.

${ }_{17}$ Ex Reinieri ad Sanctum Jacobum Monachi. Chronico Leodiensi, en Recueil, XVIII (París, 1879), 623.

${ }_{18}$ Willelmi chronica Andrensis, M. G. H. SS., XXIV (Hanover, 1879), 752; Recueil, XVIII (París, 1879), 574; esta crónica toma información de los anales del monasterio benedictino de Bergues-St. Winnoc (dep. del Norte), M. G. H. SS., VI (Hanover, 1844), 439.

${ }_{19}$ M. G. H. SS., XXXI (Hanover, 1903), 180 y 656. 
el franciscano Salimbene de Adán copia la noticia en su crónica (h. 1287) ${ }^{20}$.

La simbólica referencia a Roma como capital y ciudad santa de la cristiandad latina tiene una especial relevancia en la versión del cisterciense Cesáreo de Heisterbach (Renania). En su obra, titulada Dialogus Miraculorum (h. 1219-1223), dice así: Los albigenses, antes que viniese contra ellos el ejército del Señor, como se dice arriba, habían llamado en su socorro al Miralimomelinus, rey de Marruecos. El vino de Africa a España con una increíble multitud de gentes, con la esperanza de poder apoderarse de toda Europa. Ordenó incluso al Papa Inocencio transformar el pórtico de la iglesia de San Pedro en cuadra para sus caballos y fijar su estandarte en la cima $^{21}$. Este comentario sobre el estandarte del Miramamolín sirve a nuestro cronista para describir plásticamente el castigo a su gran soberbia: la primera de sus banderas, capturada durante la batalla, fue enviada a Inocencio, y plantada en un lugar elevado en la iglesia sobredicha para gloria de Cristo. Este dato es real y lo confirman varias fuentes en Italia, Francia e Inglaterra ${ }^{22}$.

${ }^{20}$ Crónica fratris Salimbene de Adam Ordinis Minorum, M. G. H. SS., XXXII (Hanover, 1905-1913), 28

${ }^{21}$ Berlioz, 18-19; trad. en Mondéjar, apa. CVII, 326-327. Crónica completa en Strange, J. (ed.), Dialogus miraculorum, 2 vols., Colonia-Bonn-Bruselas, 1851 [reimpr. Ridgewood, N. J., 1966].

${ }^{22}$ Berlioz, 19. El notario imperial Ricardo de San Germano dice que Alfonso VIII: mittit etiam de acceptis Sarracenorum spoliis eidem honorabilia exenia, tentorium videlicet totum sericum et vexillum auro contextum. Quod in principis Apostolorum basilica in laudem nominis Christi appensum est, Chronica, M. G. H. SS., XIX (Hanover, 1866), 355; Huici, Estudio, fuentes cristianas, ap. X, 184, y Mondéjar, ap. XIV. El tardío Mateo Palmieri (1405-h. 1475) recogió esta información en sus Anales de Florencia o Liber de Temporibus, en L. A. Muratori, Rerum Italicarum Scriptores, Citta di Castello, 1906, t. 26, parte I, p. 103, citado por Lomax, 40. En las fuentes francesas el estandarte de al-Nāșir fue enviado a Roma por Pedro II de Aragón (1196-1213). Así, Guillermo el Bretón (h. 1224) afirma: el rey de Aragón, caballero de los más nobles... en señal de victoria envió la lanza y el estandarte del mismo Mummilinus, que, todavía situadas en la iglesia de San Pedro en un lugar elevado, muestran por siempre el favor y la misericordia de Cristo gracias a los cuales dio a los suyos la victoria en esta guerra, aunque eran inferiores en número, en Chronique, 241, citado por Berlioz, 57. Lo mismo aseguran las Grandes crónicas de St. Dénis de París: en representation de la misericorde Nostre Seigneur et en signe de la victoire que Dieux li ot donnée [a Pedro II], ja soit ce que il fussent un poi de gent au regart de leur anemis, el envoia l'enseigne de ce Roi Sarrazin à l'eglise Saint Pere de Rome; si fue atachié à l'entrée du mostier, à la loenge de celui qui vit et regne sanz fin, Recueil, XVII (París, 1878), 398. La misma noticia es recogida por Alberico de Trois-Fontaines, Mondéjar, ap. CXII, y Huici, Estudio, fuentes cristianas, ap. VI, 181. En Inglaterra hay referencias a la captura del estandarte en la Chronica majora (h. 1251), de Mateo París, Recueil, XVII (París, 1878), 708. 


\section{El «complot del extranjero»}

La estrecha relación entre la cruzada anticátara del Languedoc y la cruzada antimusulmana de la Península Ibérica aparece también en los Anales de Colonia, fuente geográficamente próxima a Cesáreo de Heisterbach: [1211] Tras su marcha, los tolosanos, así como otros herejes se volvieron hacia el rey de Marruecos, Massamutus, implorando su ayuda frente a los católicos. Respondiendo a sus voces, reunió una multitud innumerable de Sarracenos para combatir y someter a su dominio la tierra de los cristianos. Cruzaron el mar e invadieron toda la tierra del rey de España, devastando todo hasta siete días de marcha; tomaron villas y plazas fuertes, matando o haciendo huir a sus habitantes cristianos. El mismo Massamutus declaró la guerra al año siguiente, el cuarto días antes de Pentecostés, a todos los que glorificaban la cruz de Cristo ${ }^{23}$.

Los rumores de alianza entre albigenses y almohades se sumaron entonces a otros no menos amenazadores, como el citado por Mateo París (h. 1251) cuando afirmaba que el rey inglés Juan Sin Tierra (1199-1216) quería convertirse al Islam y aliarse con el Miramamolín almohade ${ }^{24}$.

Esta complicidad de herejes y musulmanes en el contexto de la Cruzada Albigense y en los orígenes de la Cruzada de Las Navas ha sido denominada por J. Berlioz como el «complot de l'étranger». En relación directa con los elementos del «desafío», aparece en la Hystoria Albigensis (1218) del cisterciense Pedro de Vaux-de-Cernay, historiador «oficial» de la Cruzada anticátara, cuando acusó interesadamente al conde Raimundo VI de Tolosa (1194-1222), principal enemigo de los cruzados, de enviar mensajeros al rey de Marruecos para implorar su ayuda, no solamente en nuestras regiones, sino con vistas a la destrucción de la cristiandad entera ${ }^{25}$. De la notable difusión de este temor da cuenta también el sirventés titulado Senhor, per los nostres peccatz (¿1195-1212?) del trovador Gavaudan, quien aseguraba que el califa almohade quería invadir Occitania al grito de «Franc, faiz nos loc!, Nostres Proensa e Tolzas, Entro al Puey totz lo mejas!» ${ }^{26}$.

${ }^{23}$ Annales Colonienses, M. G. H. SS., XVII (Hanover, 1871), 826; trad. fr. en Berlioz, 54-55.

${ }^{24}$ Mateo París, Majori Anglicana Historia, Recueil, XVII (París, 1878), 704-710.

${ }_{25}$ Pedro de Vaux-de-Cernay, Hystoria Albigensis, 2 vols., ed. P. Guébin y E. Lyon, París, 1926 y 1930, vol. II, p. 91. Sobre esta cuestión, véase Roquebert, M., L'Épopée cathare, vol. II (1213-1216: Muret ou la depossesion), Toulouse, 1995 (1. ${ }^{\mathrm{a}}$ ed. 1977), 122-123.

${ }^{26}{ }^{2}$ Francos, hacednos sitio! ¡Nuestra es Provenza y el Tolosano, y todo el interior hasta Puy!, ed. M. de Riquer, Los trovadores. Historia literaria y textos, 3 vols., Barcelona, 1975, vol. II, cap. lii, núm. 208, 1049-1052. Más abajo volvemos a comentar esta interesante fuente. 
Aunque Lomax afirmó que el vínculo cátaro-almohade pudo deberse a «rumores improbables, pero no del todo increíbles», parece más razonable entenderlo como otro elemento añadido al tema del «desafío del Miramamolín» con el que Cesáreo y otras fuentes enriquecieron sus noticias sobre los acontecimientos bélicos ocurridos entre 1209 y 1213. El hecho de que, como ya observara Lomax, el duque Leopoldo VI el Glorioso de Austria (1198-1230) y otros cruzados germanos combatieran contra los albigenses antes de enrolarse en la Cruzada de Las Navas y el que varias fuentes alemanas identifiquen ambas empresas explicarían esta fusión de informaciones. En cualquier caso, estas «confusiones» no excluyen una motivación ideológica consciente de los cronistas, todos ellos eclesiásticos y testigos del clima de radicalización ideológica que envolvió el doble enfrentamiento de la christianitas contra los musulmanes de España y los herejes del Languedoc ${ }^{27}$.

\section{El desafío «oficial»: el envío de cartas}

Si en muchas fuentes el «desafío del Miramamolín» adopta forma de rumor, sin origen preciso, otras ofrecen una nueva dimensión de este episodio al mencionar el envío de cartas por parte del califa almohade. Así ocurre en la crónica de Emón (h. 1237), abad del monasterio premonstratense de Bloemhof-Werum (Groninga-Frisia): Ammiramomelinus Rex Carthaginis in tantam surrexit elationem, ut missis litteris blasfemia plenis generaliter omnes Christi cultores ad conflictum invitaret ${ }^{28}$.

De forma similar se expresa la Chronica de Mailros (h. 1270), abad del monasterio cisterciense de Dundrennan (Galloway, Escocia). Impetuosa enim et ignominiosa turba paganorum cum classe non modica per littera Hispaniae applicuerat, qui \& Christianos ad proeliandum invitaverunt ${ }^{29}$.

Esta referencia se observa también en Italia, concretamente en la Cronica di Bologna: Il Re Ormelino, il Re Massamuto, e il Re di Garsea Saraceni, e molti altre Re, Duchi, e Principi, racolssero un grande esercito di Sa-

\footnotetext{
27 Berlioz, 50; Lomax, 40-41, nota 23, citando los Annales Admutenses. Continuatio Admutensis (monasterio benedictino de Admont, Stiria), M. G. H. SS., IX (Hanover, 1851), 592. La presencia de Leopoldo VI de Austria en España también es citada por el arzobispo Ximénez de Rada (VIII, xii, 325, 31-35), y los Annales Gotwicenses, del monasterio de Goettweih (M. G. H. SS., IX, 602). Sobre la cuestión ideológica, véase mi trabajo en Heresis.

${ }^{28}$ Emonis Chronicon, M. G. H. SS. (Hanover, 1874), 475.

29 Rerum Anglicarum Scriptores, I (Oseney, 1684), 185.
} 
raceni di Majorica, di Cordova, di Marocco, e di tutta la Pagania, e con molti navili arrivarono nelle parti di Spagna, gaustando Città e Castella, disprezzando Idio e i suoi Sancti. E mandaronno lettere al Papa ch'egli rifiutasse il Papato, e il reggimento de Cristiani, allegando, che la leggi loro erano migliori che quelle de Cristiani ${ }^{30}$.

Por último, la tardía crónica catalana titulada Crònica o Llibre del Rei En Pere, escrita por Bernat Desclot más de setenta años después de los acontecimientos (h. 1285-1288), repite la noticia de las cartas de desafío: Aquest miramamoní sarraí hac son consell ab sos savis homens e dix-llur que ell havia en cor que passàs en la terra d'Espanya ab tot son poder, e que en gitàs tots les crestians d'Espanya. Es sos cavallers atorgaren ço que ell deía, e dixeren-li que molt havia pres; que més gents estaven al quart de la sua terra que no feïa en tota la crestiandat. Ab tant, aquest miramamoní s'aparellà de passar en Espanya e tramés sos missatges per totes ses terres a totes les gents qui armes sabessen portar, que venguessen e que passasen en Espanya ab ell, que ell volia gitar tots los cretians d'Espanya e que anaria tro a Roma (...). E Miramamoní tramès sos misatges al rei de Castella e als altres reis d'Espanya, que s'aparellassen de desemparar la terra, o si no que manava batalla a ells e a tots cells qui la crou adorassen. Quan lo rei de Castella e als altres reis d'Espanya (...) com sabessen que Miramamoní de Marrocs era passat en Espanya (...) e que havia manada batalla a tots los crestians del món o que li lliurassen tota la terra ${ }^{31}$.

Con la referencia expresa al envío de cartas por parte del Miramamolín, el inicial rumor sobre el reto de al-Nāșir adquiere el rango de desafío «oficial» lanzado a todos los cristianos, sólo a los hispano-cristianos, al Papa como «señor» de la cristiandad o, en el último caso, a Alfonso VIII de Castilla y a als altres reis d'Espanya.

\section{La reconstrucción del «desafío»: la carta del Miramamolín}

La mención explícita al envío de cartas de desafío posee una versión aún más elaborada y prácticamente ignorada. Se trata del relato de los Annales Lambacenses. Continuatio Lambacensis (a. 1197-1348), del monasterio be-

${ }^{30}$ Cronica di Bologna, en Rerum Italicarum Scriptores, ed. Muratori, XVIII (Milán, 1731), 251. Comentado por Lomax, 40.

${ }^{31}$ Bernat Desclot, Crònica o Llibre del Rei En Pere, ed. Soldevila, F., Les Quatre Grans Cròniques, Barcelona, 1971, cap. V, 410-411. 
nedictino de San José de Lambach (Alta Austria), fuente centroeuropea alejada de los hechos, pero muy bien informada. Por su gran interés, merece la pena citarla en su totalidad: [1211] Infinitas multitudo Sarracenorum illis diebus navigio terras Arragoniae, Hyspaniae, Navarriae aliarumque maritimarum regionum petentes, oppida, castella, munitiones destruentes, non parvam christianorum stragem fecerunt. Quorum rex in multitudine armorum confisus et alter Antyochus estimans se sydera vertice tangere, totumque suo subiugare mundum imperio, literas superbiae afflatas tonitruo christianis direxit principibus, in hunc modum: «Exmemiramoni filius Exmemiramoni, filius Miramen, omnibus regibus ete principibus christianorum, et maxime regi Arragonum et comiti de Baruh [¿Barcelona?], iram et indignationem. Gratias agimus omnipotente Deo nostro pro omnibus beneficiis quae nobis dignatus est largiri, et maxime pro illo beneficio quod contulit nobis in terra hierosolimitana, quam gens nostra et gladii nostri pugnaverunt ab inmundiciis christianorum; et nunca iterato pro victoria quam contulit nobis in expugnatione castri quod dicitur Salve Terra, in quo superbia vestra plurimum confidebat, et de quo superbia vestra multa dampna Sarracenis inferebat. Unde animadvertere potestis, quod lex Sarracenica melior est quam vestra; unde precipimus, consulimus et hortamur, si diligitis terras vestras, liberos vestros et uxores, quatenus subdatis vos imperio nostro, et transeatis ad legem nostra. Quod si facere obstinaciter recusatis, congregate omnes qui signum crucis adorant, et nobis occurrite ad conflictum, et ibi experiemini en ses nostros. Tibi autem rex Arragonum dicimus, quoniam consilio tuo et suggestione tua multa dampna illata sunt $\mathrm{Sa}$ rracenis, et dicebas aliis, quod idffaceres ex consilio domini Romae: quod si diligenter adtenderis, in perniciem christianorum non in salutem dominis Romae fecit. Nos tandem non cessabimus debelando terras vestras, ire usqua Romam, et trademus dominum Romae contumeliis et miseriis. Data apud Ispaldem [Sevilla], 8 idus Octubris» ${ }^{32}$.

Este original texto ha pasado desapercibido para la mayoría de los autores dedicados al estudio de la campaña de Las Navas de Tolosa y sus fuentes, incluso entre las investigaciones más recientes, por lo que puede considerarse en buena medida una noticia «novedosa» ${ }^{33}$.

32 Annales Lambacenses. Continuatio Lambacensis, a. 1197-1348, M. G. H. SS., IX (Hanover, 1851), 557-558. La misma información sin el texto íntegro de la carta de al-Nāșir se encuentra también en los Annales Reicherspergenses. Continuatio a. 1195-1355, M. G. H. SS., XVII (Hanover, 1851), 526.

${ }_{33}$ En un reciente trabajo titulado «Tuez-les tous, Dieu reconnaîtra les siens». La croisade contre les Albigeois vue par Césaire de Heisterbach (1994), el profesor J. Berlioz cita una re- 
Su autor data acertadamente la llegada de al-Nāṣir a la Península en la primavera de 1211 y, como otras fuentes, observa el gran volumen del ejército almohade y su capacidad de desplazamiento por mar ${ }^{34}$. Asimismo, coincide con otros relatos en la intención dominadora del «mundo» de un Miramamolín envanecido por su poderío bélico. La constante alusión a la soberbia del califa almohade se recrea aquí mediante la comparación bíblica con el rey Antíoco, enemigo del pueblo de Israel y paradigma del orgullo desmedido que es castigado por Dios ${ }^{35}$.

Con esta última versión el «desafío del Miramamolín» se materializa en el texto de una carta dirigida a todos los príncipes cristianos y especialmente al rey Pedro II de Aragón (1196-1213), pariente del duque Leopoldo VI de Austria, lugar de origen del relato ${ }^{36}$. El Miramamolín recuerda satisfecho las pérdidas de los cruzados en Oriente y la conquista de la fortaleza de Salvatierra (septiembre-1211). Al relacionar las derrotas de Tierra Santa y España, el autor no sólo demuestra una información notable - la fecha y los hechos de la campaña de Salvatierra sólo aparecen en la documentación papal ${ }^{37}$

ferencia muy concreta de Achille Luchaire a la fuente que reproducimos (Innocent III. Les royautés vassales du Saint-Siège, París, 1908, p. 47). Tras indagar en las fuentes musulmanas (Rawḍ al-qirtās y al-Bayān al-mugrib) y en algunas cristianas (De rebus Hispaniae, de Ximénez de Rada, y los Anales de Aragón, de Jerónimo Zurita), Berlioz reconoce lo siguiente: «Malheureusement le savant historien ne cite pas ses sources et nous ne savons s'il a utilisé, en le trahissant quelque peu, Césaire de Heisterbach, ou une autre source, encore à découvrir», Berlioz, 55-56, notas 20-21. Tampoco hay referencia a esta fuente en mi trabajo sobre el «desafío del Miramamolín», publicado en Heresis.

${ }^{34}$ Hay referencias similares en los Annales Claustroneoburguiensis, Annales Reicherspergenses, y en las crónicas de Bergues-St. Winoc, San Bertín y Bolonia (M. G. H. SS., IX (Hanover, 1851), 622; XVII (Hanover, 1851), 526; VI (Hanover, 1844), 439; Recueil, XVIII (París, 1879), 603; Rerum Italicarum Scriptores, XVIII (Milán, 1731), 251. Los almohades demostraron sobradamente este potencial conquistando Mallorca en 1203 y atacando la costa catalana en 1210. En relación con este hecho, el autor del texto de Lambach demuestra su lejanía del escenario de los acontecimientos al considerar Navarra un territorio marítimo.

35 La cita de la carta corresponde al Libro de los Macabeos (II, Mac 9, 10): Antíoco IV Epífanes, octavo rey de Siria (175-164 a. de J. C.), prohibió la religión judía, provocando la rebelión de los macabeos. Como el Miramamolín almohade, también escribió una carta al «pueblo de Israel». Sobre la visión del califa en la cristiandad de la época, véase mi trabajo «La imagen del Miramamolín al-Nasir (1199-1213) en las fuentes cristianas del siglo XIII», Anuario de Estudios Medievales, Barcelona (en prensa).

36 Así lo asegura Jiménez de Rada en su relato de la campaña (VIII, xii, 325, 35). Lo era por parte de su abuela Rica o Riquilda, mujer de Alfonso VII el Emperador (1125-1157), según conjetura de J. Zurita (Anales de Aragón, Lib. II, cap. LXI) que cita Soldevila, 597, núm. 24.

${ }^{37}$ La toma de Salvatierra y este nombre aparecen en la carta de 31 de enero de 1212, enviada por Inocencio III al arzobispo de Sens y sus sufragáneos para pedirles que apoyaran la empresa de Alfonso VIII (Mansilla, núms. 468, 497-498) y en la carta de los Annales Lambacenses (M. G. H. SS., IX (Hanover, 1851), 557-558). Además de estas fuentes, únicamente la crónica de San Marcial de Limoges y los Annales Claustroneoburgensis II, del monasterio de Kloster- 
sino que las concibe como episodios de una misma pugna Islam-Cristiandad librada en varios frentes, lo que es un lugar común en la mentalidad de la época.

Esta versión no plantea la batalla contra los cristianos como consecuencia de la invasión musulmana de la Península o de la resistencia de sus reyes, sino que, como la Cronica di Bologna, lo condiciona a la conversión de los príncipes europeos al Islam. En ambos casos el califa hace al Señor de Roma receptor último de sus amenazas, reconociéndole su poder y autoridad sobre el conjunto de los cristianos ${ }^{38}$.

La original carta del monasterio de Lambach es la pieza que completa la construcción del difundido episodio del «desafío del Miramamolín». El rumor que los autores de algunas fuentes «habían oído», se había concretado para otros en el envío explícito de «cartas de desafío»; en un último paso quedó «materializado» en un monasterio benedictino de la Alta Austria al que «llegó» el texto completo de la carta que el califa almohade había enviado a los príncipes cristianos comunicándoles sus ambiciosos proyectos de conquista de la Cristiandad ${ }^{39}$.

\section{LA FECHA DEL «DESAFÍO DEL MiRAMAMOLÍN»}

Vistos los diferentes testimonios que las fuentes de toda Europa ofrecen del «desafío del Miramamolín» y el proceso de enriquecimiento de los diversos relatos, hay que preguntarse cuándo se conoció esta noticia.

La carta del arzobispo de Narbona Arnaldo Amalarico, escrita el 11 de agosto de 1212 según los Annales Waverleienses, deja claro que los participantes en la campaña de Las Navas conocían el famoso desafío de al-Nāṣir. También era sabido antes del 5 de abril, fecha de la carta en la que Inocencio III insinuaba las amenazas a gran escala del califa almohade. Antes de esta fecha, las fuentes más precisas permiten establecer tres momentos en los que pudo haberse conocido el «desafío».

neuberg (ibid., 622), distinguen entre la ofensiva almohade de 1211 y la batalla de 1212 , aunque sin añadir otros datos.

${ }_{38}$ Así era conocido el papa entre los musulmanes; véase Ibn 'Id̄ārī al-Marrākušı (m. 1312), al-Bayan al-mugrib, en Huici, Estudio, fuentes árabes, ap. I, 120.

${ }_{39}$ Con el envío de cartas de desafío a los reyes hispano-cristianos, el modelo observado en las crónicas musulmanas relativas a Sagrajas-Zallaqa adquiere plena validez entre las fuentes europeas cristianas relativas a la batalla de Las Navas de Tolosa. Véase mi trabajo en $\mathrm{He}$ resis. 


\section{Antes de la caída de Salvatierra (1211): el impacto de Alarcos}

Esta datación lleva a pensar en el gran eco provocado por el desastre castellano de Alarcos (19 de julio de 1195), derrota que resucitó el temor a los almohades en una Europa que no había superado aún el mazazo de las pérdidas sufridas en Tierra Santa ante Saladino (1187) y el semifracaso de la III Cruzada (1189-1192) ${ }^{40}$. Aunque es cierto que la crisis de Alarcos fue grave, hay que señalar que las imágenes de gran peligro colectivo también pueden encontrarse en acontecimientos anteriores a $1195^{41}$. Además, no debe olvidarse que el clima de peligro suscitado por esta derrota no sólo cruzó los Pirineos de forma espontánea, sino que fue promovido por las cortes hispanas, sobre todo por parte de la de Alfonso VIII de Castilla.

Como ya observara Lomax, un instrumento clave en esta labor «publicitaria» fue el Capítulo General del Císter ${ }^{42}$. Otros excelentes propagandistas de la realidad hispana fueron los trovadores al servicio de las cortes de Castilla y Aragón, donde siempre fueron protegidos y bien acogidos ${ }^{43}$. El temor a una nueva «pérdida de España» y la necesidad de una gran coalición antimusulmana a raíz del desastre de Alarcos fue cantada por el trovador Fulco o Folquet de Marsella (h. 1178-1231) en la cansó de crozada titulada

40 Buena parte de las crónicas europeas que aluden a la derrota de Alarcos fueron recogidas por Lomax, 38, notas 6-7. La sensación de derrota queda patente en la carta enviada por el papa Celestino III a Sancho VII de Navarra el 29 de marzo de 1196: Habiéndonos visitado duramente la mano del Señor para castigo de nuestros crímenes y habiendo permitido que la violencia de los paganos ocupe las fronteras de los cristianos, tanto en Oriente como en Occidente (Huici, Estudio, fuentes cristianas, ap. XIII, 185). Lo mismo refleja la Historia rerum Anglicarum (h. 1198) del agustino inglés Guillermo de Newburgh, en Rerum Britannicarum Scriptores, Heidelberg, 1587, p. 484.

${ }^{41}$ La portuguesa Chronica Gothorum retrasa la idea de una reconquista musulmana de la Península a la campaña del califa almohade Abū Ya'qūb Yūsuf (1163-1184), abuelo de al-Nāṣir, contra Santarem en 1184 (Viguera, M. J., Los reinos de taifas y las invasiones magrebíes, Madrid, 1992, 280-282), en Portugaliae Monumenta Historica Scriptores, Neudeln, Leichenstein, 1967 (Lisboa, 1856), vol. I, pp. 16-17. Con todo, esta noticia podría ser un ejercicio retórico o una translación errónea de noticias de las campañas de Alarcos o de Las Navas a sucesos anteriores.

${ }^{42}$ Lomax, 38-39; sobre esta cuestión, véase Mahn, J. B., L'Ordre cistercien et son gouvernement, París, 1851, 173-216, especialmente p. 241.

43 García de Cortázar, J. A., «Cultura en el reinado de Alfonso VIII de Castilla: signos de un cambio de mentalidad y sensibilidades», Alfonso VIII y su época, II Curso de Cultura Medieval, Aguilar de Campoo, 1990, 167-194, esp. 181-182 y 188; Anglade, J., Histoire sommaire de la litterature meridional au Moyen Age, París, 1921, 118-121; Milá y Fontanals, M., De los trovadores en España, 2. ${ }^{\text {a }}$ ed. en Obras completas, dir. de M. Menéndez y Pelayo, vol. II, Barcelona, 1888-1893, p. 126; Siberry, J. E., Criticism of crusading, 1095-1274, Oxford, 1985, p. 5; sobre los trovadores y España, Riquer, Los trovadores, y Alvar, C., La poesía trovadoresca en España y Portugal, Barcelona, 1977. 
Hueimais no y conosc razo, composición que sirvió para excitar los ánimos de cara a futuras campañas, especialmente en los momentos previos a la de $1212^{44}$.

Otros famosos trovadores relacionados con las cortes hispanas como Peire Vidal (h. 1183-h. 1204), Raimbaut de Vaqueiras (h. 1180-h. 1205) y Guilhem Ademar (h. 1195-h. 1217) también apelaron en varias de sus composiciones a la unidad de los reis d'Espanha frente al enemigo común musulmán, un deseo que finalmente se haría realidad en la futura campaña de Las Navas de Tolosa ${ }^{45}$.

En este contexto de temor atribuido al desastre de Alarcos ha sido incluida otra composición trovadoresca que sí tiene relación directa con el «desafío del Miramamolín». Se trata de la ya citada cansó de crozada de Gavaudan (h. 1195-h. 1211), trovador protegido por Alfonso VIII y posible testigo de la misma batalla ${ }^{46}$, que dice así: I. Senhor, per los nostres peccatz / creys la forsa dels sarrazis: / Jherusalem pres Saladis [1187] / et encaras non es cobratz; / perque manda.l reys de Marroc / qu'ab totz los reys de crestian / se combatra ab sos trefas / andolozitz et arabitz / contra la fe de Crist garnitz... III. Tant an d'erguelh selhs qu'a triatz / qu'els cujo.l mons lor s'aclis; / marroquenas, marabetis / pauzons a mons, per mieg los pratz. /Mest lor gabon: "Franc, faiz nos loc! / Nostr'es Proensa e Tolzas, / entro al Puey totz lo mejas!» (...) / qu'ab penedens'er perdonatz / lo peccatz... [¿la Cruzada de 1212?] VI. Nos laissem nostras heretatz, / pus qu'a la gran fe em assis, / a cas negres outramaris; / qu'usquecx ne sia perpessatz / enans que.l dampnatge nos toc: / portogals, gallicx, castellas, / navars, aragones, serdas / lur avem en barra gequitz, / qu'els an rahutatz et aunitz. VII. Quan veyran los baros crozaz: / alamans, frances, cambrezis, / engles, bretos et angevis, / biarns, gascos, ab nos mesclatz, / e.ls provensals, totz en un floc: / saber podetz qu'ab los espas / romprem la preyss... tro.ls ajam mortz totz e delitz...

${ }^{44}$ Hueimais no'y conosc razo / ab que nos puscam cobrir, / si ja Dieu volem servir, / pos tant enquer nostre pro / que son dan en volc sufrir: / que'l Sepulcre perdet premeiramen / et ar sufre qu'Espanha's vai perden, ed. Riquer, vol. I, cap. xxvii, núm. 112, 600; otras referencias en Milá, 118; González, I, 1000, y Alvar, 93-98. La fecha de composición, según C. Alvar, puede fijarse entre julio de 1195 y la muerte del rey Alfonso II de Aragón, ocurrida el 26 de abril de 1196.

${ }^{45}$ Riquer, II, cap. xl, 811 y ss., xli, 859 y ss., y lviii, 1100 y ss.; Alvar, 77 y ss. El papel de los trovadores occitanos como difusores de la campaña de 1212 es reconocido por Huici, Las grandes batallas, 229; González, I, 1000-1002, Alvar y Riquer, op. cit. En la batalla de Las Navas combatieron los trovadores catalanes Guillem de Cabestany y Huguet de Mataplana formando parte del ejército de Pedro II de Aragón; véanse Riquer, II, liv, 1063-1078, y lvi, 10881089, y Alvar, 117-121.

46 Anglade, 121. 
VIII. Profeta sera.N Gavaudas / E Dieus er honratz e servitz / on Bafomet era grazitz ${ }^{47}$.

Esta cansó de crozada de Gavaudan tiene un problema de datación que afecta directamente al «desafío del Miramamolín»: unos autores la fechan tras la batalla de Alarcos y otros en vísperas de la campaña de Las Navas ${ }^{48}$. La imagen de soberbia que Gavaudan ofrece del Miramamolín, la referencia a la pérdida de Jerusalén ante Saladino (1187) y el dato sobre el condado de Poitou parecen acercar esta cansó a la batalla de Alarcos ${ }^{49}$. Sin embargo, el tema del «desafío del Miramamolín» vincularía dicha composición a la campaña de Las Navas de Tolosa, puesto que encaja perfectamente en el contexto en el que todas las demás fuentes lo recogen, es decir, entre los años 1211 y 1212.

Si la canción de Gavaudan fuera consecuencia de la derrota de Alarcos, el «desafío del Miramamolín» podría datarse ya entre quince y veinte años antes de la batalla de Las Navas de Tolosa, es decir, coincidiendo con algunas informaciones que aluden a un clima de confrontación a gran escala entre cristianos y almohades, bien deseado, bien temido, en los años próximos a 1195. En esta hipótesis el tema del «desafío del Miramamolín», es decir, su supuesta voluntad de combatir contra todos los cristianos, puede considerarse un recurso ideológico-propagandístico vigente en Europa occidental durante el período de más sensible presión musulmana a ambos lados del Mediterráneo (h. 1187-1212), asociado al tema de los almohades y recurrente en momentos de temor a nuevas ofensivas norteafricanas, como fue el caso de los años 1211-1212.

Además de las noticias derivadas del desastre de Alarcos, otras fuentes sitúan el «desafío del Miramamolín» antes de la primavera de 1211. Ello ocurre en las crónicas de Guillermo el Bretón, Alberico de Trois-Fontaines y la iglesia de Saint-Dénis, todas ellas de origen francés y texto muy similar. En estos casos, los cronistas se centran en la batalla e ignoran o no citan detalle alguno sobre la conquista de Salvatierra, por lo que su precisión cronológica es escasa y poco fiable.

La versión de Cesáreo de Heisterbach también es anterior a 1211, aunque más próxima a la campaña de 1212. Este autor cisterciense situó el llama-

${ }^{47}$ Riquer, II, lii, núm. 208 (Senhor, per los nostres peccatz), 1049-1052.

${ }^{48}$ Especialistas como M. de Riquer o C. Alvar se inclinan por la fecha de 1195, siguiendo la argumentación de I. Frank, aunque no sin dudas. Sobre esta polémica, véanse los análisis de Riquer, II, LII, núm. 208, 1049, y Alvar, 89-91.

${ }^{49}$ La cansó dice y el rey inglés, conde pictavino. Ricardo I (1189-1199) fue conde de Poitiers, pero no Juan Sin Tierra (1199-1216), por lo que la fecha de composición se retrasaría a 1195. 
miento de los herejes occitanos al Miramamolín antes de la llegada al Languedoc del ejército cruzado anticátaro, esto es, antes de 1209. Tampoco este dato es del todo fiable, puesto que el monje renano no concibe el origen de la campaña de Las Navas en sí mismo, sino en función de los sucesos de la Cruzada Albigense, proclamada en $1208^{50}$.

\section{Tras la conquista de Salvatierra: el origen de la Cruzada de 1212}

El origen del «desafío del Miramamolín» podría fecharse también entre septiembre y principios de octubre de 1211. En primer lugar, hay que citar a los originales Annales del monasterio de Lambach, que ofrecen una datación muy precisa: la carta del califa almohade está fechada en Sevilla el 8 de los idus de octubre de 1211, es decir, poco después de la conquista de Salvatierra, verdadero detonante de la batalla campal de $1212^{51}$. En este sentido es interesante observar que la carta de Lambach a los príncipes cristianos es casi simultánea a la que el Miramamolín envió al jeque Abū Muḥammad 'Abd al-Wāhid, señor de Ifrīqiya, el 13 de septiembre de 1211 relatando su victoria de Salvatierra ${ }^{52}$.

Sólo otra fuente, también germánica, informa con inhabitual precisión sobre la fecha del «desafío». Se trata de los Anales de Colonia, que sitúan la embajada de los albigenses en la corte almohade en la segunda mitad de 1211, es decir, tras la campaña de Salvatierra, añadiendo: el mismo Massamutus declaró la guerra el año siguiente, el cuarto día antes de Pentecostés, a todos los que glorificaban la cruz de Cristo ${ }^{53}$. Esta fecha es muy tardía, pues corresponde a un día de mayo, es decir, después de la carta del 5 de abril en la que el papa Inocencio III daba noticia de las intenciones del califa almohade. Además, como Cesáreo de Heisterbach, el autor de los Anales

${ }^{50}$ Cesáreo de Heisterbach citado y traducido por Berlioz, 18.

${ }^{51}$ Sobre esta cuestión, véase Alvira Cabrer, M., «De Alarcos a Las Navas de Tolosa. Idea y realidad de los orígenes de la batalla de 1212», en Actas de Alarcos 1195. Congreso Internacional VIII centenario de la batalla de Alarcos, Ciudad Real (del 3 al 6 de abril de 1995), coord. R. Izquierdo y F. Ruiz, Cuenca, 1996, 249-264.

${ }_{52}$ Al-Hiimyarī (m. 1326) cita algunos párrafos en su Kitāb al-Rawd al-mi ‘̦tār (Huici, Las grandes batallas, 314-315); también la inserta Ibn 'Id̄ārī en su al-Bayān al-mugrib (Huici, Estudio, fuentes árabes, ap. I, 117-119). Esta carta describe la toma de Salvatierra, pero ninguna de las versiones alude a futuras campañas contra los cristianos y, mucho menos, a «desafíos» globales a la cristiandad. En todo caso, la conexión entre ambas cartas resulta harto improbable.

${ }^{53}$ Berlioz, 55. 
de Colonia narra la campaña de 1212 en función de la Cruzada Albigense, lo que le resta credibilidad ${ }^{54}$.

También el obispo Lucas de Tuy data el «desafío» antes de la cruzada al asegurar que, tras conocer la gran movilización cristiana, al-Nāṣir se arrepintió de haber retado soberbiamente a la cristiandad (no se dice si antes o después del verano de 1211) ${ }^{55}$.

En los relatos de las crónicas de Emón, Mailros, Bolonia y en los Anales Toledanos $I$ no se precisa una fecha, pero todas coinciden en que fueron las amenazas del califa las que provocaron la gran cruzada internacional de 1212. El «desafío» encaja entonces con la actitud orgullosa de un califa conquistador de Salvatierra que confía en su potencial bélico de cara a un inminente choque contra los cristianos ${ }^{56}$.

\section{Después de la predicación de la Cruzada: la respuesta a la gran batalla querida por los cristianos (29 septiembre 1211/abril 1212)}

Una última datación posible procede de la Crónica Latina de los Reyes de Castilla, fuente muy próxima a los hechos. Aquí el «desafío del Miramamolín» no provoca la Cruzada, sino que es la respuesta «soberbia» de alNāṣir a los grandes preparativos cristianos: al conocerlos, se sintió poderoso para bellare contra omnes qui signum Crucis adorabant.

Esta posibilidad resulta verosímil por varias razones. De un lado, es cierto que los almohades tuvieron noticia de los excepcionales preparativos cristianos previos a la campaña de Las Navas de Tolosa ${ }^{57}$. A ello se añade la

${ }^{54}$ El domingo de Pascua oscila entre el 22 de marzo y el 25 de abril. En el año 1212 fue el 25 de marzo, de modo que Pentecostés fue el 13 de mayo: la fecha corresponde al miércoles 9 de mayo.

55 Huici, Estudio, fuentes cristianas, ap. V, 179.

${ }^{56}$ Cristianos y musulmanes constatan la desmedida confianza de al-Nāșir tras la conquista de Salvatierra. Jiménez de Rada afirma: El agareno, tras apoderarse de la fortaleza de Salvatierra, regresó muy engreído a su tierra (VII, xxxvi, 305, 3-4), y al-Himyarī: El rey al-Nāṣir se vanaglorió con la toma de Salvatierra, lo escribió a sus dominios y se le ocultaron las causas oscuras que iban a provocar la derrota de al-'Iqāb (Huici, Las grandes batallas, 315-316).

57 Así lo atestigua el Kitāb al-Bayān al-mugrib de Ibn 'Idārī: Fueron sus frailes y sacerdotes [de Alfonso VIII] desde Portugal hasta Constantinopla, gritando desde el mar de los griegos hasta el mar verde: ‘Socorro, socorro; misericordia, misericordia! Llegaron los siervos de la Cruz, de todo desfiladero profundo y de todo país lejano... [al rey de Navarra, aliado de los almohades] maldíjolo el señor de Roma, si no guerreaba al lado de su gente y se unía a los príncipes de su religión; unióse, pues, a este ejército con ardor y se metió en aquel mar revuelto en 
actitud soberbia del Miramamolín, un lugar común en la cronística medieval por razones ideológicas que, en el caso de al-Nāșir, parece ajustarse a la realidad según los testimonios coincidentes de las fuentes ${ }^{58}$.

Por último, esta datación es la única que se ajusta al objetivo último de la gran Cruzada de 1212: la batalla campal contra el ejército almohade, objetivo que Alfonso VIII hizo público a todo su reino en un edicto promulgado el 29 de septiembre de 1211 y que desde poco después (hacia finales de octubre) comenzó a ser predicado por sus emisarios al norte de los Pirineos ${ }^{59}$. Siendo esta batalla campal el elemento clave común a todas las versiones del «desafío del Miramamolín», parece posible que el victorioso y soberbio al-Nāșir, tras conocer la voluntad cristiana de combatir a sus tropas en campo abierto y el masivo reclutamiento de tropas cristianas fuera de la Península, aceptara el envite y retara a todos los cristianos a la anunciada batalla decisiva.

GÉNESIS DEL «DESAFÍO DEL MIRAMAMOLÍN»

\section{El origen almohade}

En primera instancia, es lógico pensar que el «desafío» de Miramamolín partió del propio califa almohade. Sin embargo, ninguna de las fuentes musulmanas conocidas afirma que al-Nāșir buscara premeditadamente una

\footnotetext{
el que todos invocaban la Cruz (Huici, Estudio, fuentes árabes, ap. I, 120); 'Abd al-Wāhid al-Ma-

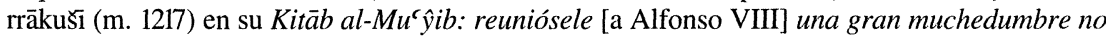
sólo de la península, sino también de Oriente, tanto que llegó su clarín hasta Constantinopla (ibíd., ap. II, 121-122); Ibn Abī Zar' (m. 1327) en su Raw ḍ al-qirtās: [Alfonso VIII] levantó sus cruces insensatas en todos los países infieles y acudieron los reyes cristianos con sus ejércitos magníficamente equipados, llenos de fuego para combatir (ibíd., ap. IV, 127), y al-Himyarī en su al-Rawd al-mi'tar: pidió Alfonso ayuda a la gente de su religión y los excitó a defenderla. Le respondieron y se le unieron de todas partes (Huici, Las grandes batallas, 316).

${ }^{58}$ La soberbia de al-Nāṣir aparece también antes de la toma de Salvatierra, según algunas fuentes musulmanas: el Raw ḍ al-qirtās de Ibn Abī Zar` asegura que Annasir se envaneció ante aquel inmenso ejército (Huici, Estudio, fuentes árabes, ap. IV, p. 125); en su Kitāb al-`Ibar Ibn Jaldūn (s. XIV) dice que al-Nāṣir no siguió el consejo del jeque Abū Muḥammad al-Hafṣí, opuesto a una campaña contra los cristianos (ibíd., III, 123), y el tardío al-Maqqarī (m. 1632) recoge la noticia de Ibn Abī Zar` en su Nafh al-fịb: Anasir se complació tanto con el número de sus soldados que se tuvo por invencible (ibíd., V, 131). Rodrigo Jiménez de Rada ofrece la misma imagen en los momentos previos a la batalla: $Y$ como entendiera el agareno que no plantábamos batalla, envanecido, no creyó que ocurría por precaución, sino por miedo, y por ello envió cartas a Baeza y Jaén, anunciando que había copado a tres reyes y que no aguantarían más de tres días (VIII, viii, 319, 35-38).

${ }^{59}$ Crónica Latina, 25, 11-20; Jiménez de Rada, VII, xxxvi, 305, 4-12.
} 
gran batalla campal contra los cristianos ni antes, ni durante, ni después de las campañas de Salvatierra y/o Las Navas de Tolosa y, mucho menos, que pensara llevar sus tropas más allá de las fronteras «castellanas» de su imperio situadas en la línea del Tajo.

Sin embargo, recordando el documentado envío de cartas de desafío por parte de Yūsuf ibn Tašufin a Alfonso VI de León y Castilla en vísperas de la batalla de Zallāqa-Sagrajas (1086), podría plantearse la realidad histórica de un «desafío del Miramamolín», cuya referencia escrita se desconoce o fue silenciada por los cronistas musulmanes tras el desastroso final de la batalla de Hisn al-' Iqāab ${ }^{60}$

Aunque nada prueba esta hipótesis, la idea de una ofensiva musulmana global contra todos los cristianos peninsulares sí tiene un claro origen almohade. El año de su muerte, el califa ‘Abd al-Mu’min (1130-1163) planeó una gran ofensiva anticristiana, y dijo a sus jeques: "Dividiremos las tropas contra los cristianos de al-Andalus en cuatro partes»; el cronista Ibn Șāhị al-Șalā le contestó así: La parte de Ibn al-Rink [Alfonso Enríquez, rey de Portugal], en Coimbra, es la primera; la parte del Baboso [Fernando II de León] en Ciudad Rodrigo, la segunda; la de Alfonso [VIII de Castilla], en Toledo, es la tercera, y la parte de Barcelona [Alfonso II de Aragón] es la cuarta.» ${ }^{61}$

Con todo, aún con el precedente de Zallāqa y el gran el proyecto de 'Abd al-Mu'min, es bastante dudoso que en 1212 al-Nāsir buscara intencionadamente el choque frontal contra «todos los cristianos», aunque fuera consciente de su inminencia y dimensiones y tomara numerosas medidas para afrontarlo con garantías. Como atestiguan Lucas de Tuy y el arzobispo Jiménez de Rada, la llegada del poderoso contingente ultramontano reclutado por la Cruzada intimidó al Miramamolín, cuya estrategia fue, en todo momento, defensiva. Incluso tras la retirada de las tropas extranjeras, alNāsir siempre concibió el enfrentamiento en batalla campal como un último recurso evitable ${ }^{62}$

${ }^{60}$ Esta posibilidad no es nada descabellada: antes de la batalla de Zallāqa-Sagrajas (19-octubre-1086) hubo un intercambio de cartas entre Alfonso VI de León y Castilla y Yũsuf ibn Tasufin para fijar el día de la batalla. Sobre esta cuestión, véase Viguera, 170-171, que cita el «parte de guerra» del caudillo almorávide posterior a la batalla analizado en Lévi-Provençal, E., y García Gómez, E., «Novedades sobre la batalla de al-Zallāqa», Al-Andalus, XV (1950), 114 124. Véase también la primera parte de mi trabajo de Heresis.

${ }_{61}$ Ibn Sahib al-Salā (m. h. 1198), Al-Mann bi-l-Imāma, ed. A. Huici Miranda, «Textos medievales», núm. 24, Valencia, 1969, p. 56. Obsérvese que no se menciona a Navarra.

62 Lucas de Tuy asegura: [al conocer llegada de ultramontanos] de ahí que, por entonces, no tratase de atacar a los cristianos, sino solamente de defenderse [Huici, Estudio, fuentes cris- 
Lo evidente es que, si partieron de la corte almohade, las amenazas del califa fueron un recurso ideológico-propagandístico destinado a elevar la moral de sus propias fuerzas antes de la campaña de 1211, y/o a acrecentar el temor de los cristianos tras la impactante derrota de Salvatierra y/o, como hemos dicho ya, a desafiar orgullosamente el anuncio de batalla proclamado por Alfonso VIII.

Aun así, que el «desafío del Miramamolín» partiera de Sevilla es sólo una posibilidad indemostrable ${ }^{63}$. Al menos tanto como otra tampoco descartable: que la noticia del «desafío» llegara a tierras musulmanas procedente del norte cristiano y que, con la misma finalidad propagandística, fuera reimpulsada por los propios almohades de cara a la gran batalla esperada para el verano de 1212 .

\section{El origen castellano}

Si alguien tenía interés en crear un clima de tensión bélica frente a la ofensiva almohade de 1210-1211 era el rey de Castilla, aunque tampoco conviene olvidar los belicosos proyectos de Pedro II de Aragón antes de la ruptura de hostilidades con los musulmanes ${ }^{64}$.

Desde la derrota de Alarcos, el monarca castellano se distinguió por su gran labor publicitaria, logrando que el «tema de los almohades» volviera a ponerse de moda entre los europeos. Para ello empleó, como vimos, la capacidad comunicadora de los trovadores y del Capítulo General del Císter, convirtiéndose - en palabras de Lomax - en el primer rey europeo en utilizarlo como «medio de comunicación social» a nivel continental. Si la campaña de 1212 atrajo a un buen número de tropas ultramontanas fue posible, en buena parte, a esta «mentalización» promovida por Alfonso VIII desde $11955^{65}$. Por ello, cabe pensar que la difusión del rumor del «desafío del Miramamolín» partió de la corte castellana, la más interesada en promover una cruzada antialmohade.

\footnotetext{
tianas, ap. V, 179; Jiménez de Rada lo confirma: [al-Nāșir] no tenía la intención de combatir, ya que recelaba de los refuerzos extranjeros (VIII, vii, 316, 5-6). Con la misma intención evasiva el Miramamolín bloqueó Sierra Morena para obligar al ejército cristiano a retirarse antes de combatir y acosarlo en el camino de regreso al norte.

63 A. Huici lo creyó un rumor falso (Las grandes batallas, 249); J. González lo admitió como rumor, ateniéndose a los testimonios de Arnaldo Amalarico, Gavaudan y la Crónica latina, y lo fechó como ésta después de la predicación de la cruzada (González, I, 1024-1025).

${ }_{64}$ En carta del 16 de febrero de 1210 Inocencio III ordenó al arzobispo de Toledo y sus sufragáneos animar la unión de Alfonso VIII a los planes de Pedro II, en Mansilla, núm. 416, 436

${ }^{65}$ Lomax, 38-39.
} 
Esta procedencia, sin embargo, sólo tiene constancia en una de las fuentes de Las Navas de Tolosa. Se trata de la tardía e interpolada Crónica de Veinte Reyes (aprox. 1270-1312), en la que el origen del «desafío del Miramamolín» parte de Castilla, aunque no de Alfonso VIII: Después nasció el infante don Ferrando... e quando él ouo diez e seis años sintióse mucho mal de la deshonrra que su padre rresçibiera de los moros [en Alarcos] e enbió [de] mandar cruzada al papa, e enbió desafiar a Miramamolín que le daríe batalla dende a vn año do él quisiese ${ }^{66}$.

Este original dato se ajusta al belicoso ánimo del infante Fernando de Castilla (1191-1211), quien antes de febrero de 1211 había escrito al papa Inocencio III, haciéndole saber su voluntad de combatir a los musulmanes ${ }^{67}$. Este carácter guerrero lo confirma el obispo-autor de la Crónica Latina, aunque dista un tanto de la imagen ofrecida por el Toledano, para quien el primogénito de Alfonso VIII era una persona más cabal y prudente que su padre ${ }^{68}$. Con todo, la carta papal no menciona en absoluto el desafío citado por la Crónica de Veinte Reyes, reto que, además, es muy anterior a la campaña de Salvatierra y a la decisión de celebrar la batalla. A ello se

${ }^{66}$ Crónica de Veinte Reyes, Lib. XIII, cap. xxv (xxiv), p. 280, ed. y estudio de Alvar, M.; Martínez Díez, G.; Fradejas, F.; Ruiz Asencio, J. M., y Hernández, C., Burgos, 1991. Estos autores encuadran esta crónica en el taller historiográfico de Alfonso X el Sabio de Castilla (1252-1284) y sus sucesores. En texto y criterios coincide con la llamada Tercera Crónica General, publicada por Florián de Ocampo (Zamora, 1541), puesto que, según D. Catalán, ambas derivan de una previa Versión crítica de la Crónica General, hoy desaparecida. Esta constituiría un eslabón intermedio entre la Primera Crónica General, publicada por R. Menéndez Pidal (ed. 1906, 1955 y 1977) y la Crónica de Veinte Reyes, aunque para el reinado de Alfonso VIII las estructuras de las Crónicas Generales son tan dispares que toda relación entre ellas es muy problemática. Sobre esta cuestión, véase el estudio citado, pp. 13-29, p. 24.

${ }_{67}^{6}$ La respuesta pontificia consta en una carta, de fecha 22 de febrero de 1211, en la que el papa le comunica que ha interesado a varios obispos hispanos en su proyecto antimusulmán: Cum personam tuam inter christianissimos principes speciali prerrogativa in Domino amplexemur, preces ac petitiones tuas, in quibus possumus, libenti animo exaudimus, et ad ea gartanter intendimus, que devotionis tue novimus complacere (Mansilla, núms. 448, 476-477). González fecha esta contestación el 10 de diciembre de 1210 (I, 985, nota 17 citando a Migne, J., Patrología Latina, t. CCXVI, col. 353).

${ }^{68}$ El autor de la Crónica Latina retrata así al infante Fernando: Factus autem gradiusculus, circa finem adolescencie prudenciam induens, cum robore iuuenilis etatis cepit omnia predicta uilipendere et armorum usui cepit iuиari, libenter adherens illis, quos in armis strenuos nouerat et rerum bellicarum expertos. Ardebat desiderio guerre Sarracenorum, illam tractans cum famililaribus et eam sepe uolens in animo, nec ei iam studium aliud placere poterat nisi milicia et usus armorum (23, 1-7); por su parte, el arzobispo de Toledo asegura que cuando $\mathrm{Al}$ fonso VIII se encontraba a la defensiva y los almohades habían tomado Salvatierra (sept. 1211): el noble Alfonso... aunque estaba decidido a arrostrar la dudosa suerte del combate, ante los insistentes ruegos de su hijo primogénito Fernando, que pensaba con mayor clarividencia, determinó dejar para el año siguiente el riesgo del combate (VII, xxxv, 305, 18-22). 
suma que el cronista no establece una relación directa entre el desafío del infante castellano y la invasión almohade ${ }^{69}$. Estas razones, unidas al carácter apócrifo de muchos de los pasajes de la batalla de Las Navas de Tolosa en dicha Crónica, permiten considerar esta versión del «desafío» una variante de los hechos tardía y con pocos visos de realidad.

Entre septiembre y octubre de 1211 Alfonso VIII decidió combatir en batalla campal al ejército almohade ${ }^{70}$. Para ello quiso convertir la futura campaña en una gran cruzada con apoyo de los reyes hispánicos, el papado y el mayor número posible de príncipes cristianos ${ }^{71}$. Aunque los reyes y grandes señores ultramontanos no se unieron a la empresa, la propaganda de Alfonso VIII y la convocatoria papal de cruzada al clero de Francia y Provenza (carta de 31 de enero de 1212) lograron interesar a numerosos cruzados provenzales, vieneses (de Vienne), poitevinos, gascones, franceses, bretones, italianos, frisones, sajones, westfalianos y austríacos, quienes acudieron a la Península al mando de los arzobispos de Narbona y Burdeos y del obispo de Nantes $^{72}$.

Sin embargo, de los mensajes de auxilio castellanos sólo resta una carta dirigida a Felipe Augusto de Francia en la que no se menciona el «desafío del Miramamolín» ${ }^{73}$. Por ello es difícil afirmar que esta noticia procediera de Castilla. Del mismo modo, la noticia aparecida en la carta escrita por Inocencio III también pudo provenir de los emisarios del rey castellano, pero tampoco en este caso hay datos que permitan confirmarlo.

\section{A MODO DE CONCLUSIÓN: EL INCIERTO RUMOR DEL «DESAFÍO DEL MIRAMAMOLÍN»}

Resulta prácticamente imposible establecer el origen cierto del «desafío del Miramamolín». De hecho, no se puede asegurar ni siquiera su «realidad histórica». Resta, por tanto, considerarlo un rumor de gran difusión espaciotemporal, cargado de intencionalidad ideológico-propagandística y enmar-

69 ...llegó mandado al rrey cómmo miramamolín de Marruecos era pasado aquén mar con grand poder de moros que veníe contra él por le astragar toda la tierra... (Crónica de Veinte Reyes, XIII, xxvii (xxvi), 281).

70 Jiménez de Rada, VIII, xxxvi, 305, 3-7, y Crónica Latina, 25, 11-16.

71 González, I, 996 y ss.; Jiménez de Rada, VIII, i, 307, 8-10.

72 Mansilla, núms. 468, 497-498; Crónica Latina, 27, 9-22.

73 González, III, núms. 890, 557-558; trad. en Gorosterratzu, J., Don Rodrigo Jiménez de Rada, gran estadista, escritor y prelado, Pamplona, 1925, p. 74. 
cable en el contexto de la grave crisis bélico-religiosa que rodeó la Cruzada de $1212^{74}$

$\mathrm{Su}$ origen cronológico se ajusta a este enfrentamiento, aunque algunos elementos recurrentes puedan apreciarse ya en testimonios referidos a la derrota de Alarcos e incluso a ofensivas almohades anteriores, tanto en fuentes cristianas como musulmanas ${ }^{75}$.

Hacia 1195 la sensación de presión militar experimentada por la Europa cristiana frente a un Islam victorioso en Oriente y en la Península Ibérica había generado un clima de temor estimulado interesadamente por los principales afectados por estas derrotas —en el caso peninsular, los reyes hispanocristianos - mediante poderosos instrumentos publicitarios, tales como los trovadores y el Capítulo General del Císter. La crisis de Alarcos alimentó el miedo a un ataque masivo por parte del imperio almohade o a una invasión de la península y de las tierras ultrapirenaicas más próximas, «miedos» que están presentes en el origen del rumor sobre el «desafío del Miramamolín» y que reflejan sus posteriores exageraciones ${ }^{76}$.

${ }^{74}$ Como rumor se entiende «una proposición específica... que se pasa de persona a persona, por lo general oralmente, sin medios probatorios seguros para demostrarla», Allport, G. W.; Postman, L., Psicología del rumor, Buenos Aires, 1973, p. 11. Aunque esta obra aborda la cuestión del «rumor en tiempo de guerra» en relación con la población de Estados Unidos durante la Segunda Guerra Mundial, sus conclusiones son, en general, válidas para el tema que nos ocupa, puesto que - como afirman sus autores- «nuestras necesidades emocionales y cognoscitivas no se diferencian de las de nuestros antepasados» (p. 178).

Dos son las claves psicológicas del rumor: la importancia del tema para el difusor y el receptor y la ambigüedad en el conocimiento de la realidad. «En tiempos de guerra — por tantolas condiciones para la proliferación de rumores son óptimas. Los sucesos militares son sumamente importantes...», mientras que «el secreto militar junto con la natural confusión de una nación en armas y los movimientos imprevisibles del enemigo, ayudan a crear una profunda ambigüedad» (pp. 15-17). A ello hay que añadir que los efectos del rumor en las sociedades preindustriales eran mucho mayores que en las sociedades contemporáneas debido a la escasez de las noticias, a su escasa precisión y a la magnitud de los peligros que amenazaban a grandes sectores de población (p. 173).

Sobre el rumor en la Edad Media y su difusión en los exempla, véase Berlioz, J., «L'homme au crapaud. Génèse d'un exemplum médiéval», Tradition et Histoire dans la culture populaire. Rencontres autour de l'oeuvre de Jean-Michel Guilcher, Grenoble, Musée Dauphinois (20-21 janvier 1989), Grenoble, 1990 (Documents d'ethnologie régionale, vol. 1), pp. 163-203; Gavaurd, C., «La Fama, une parole fondatrice», Médiévales, 24 (1993), 5-13; Campion-Vincent, V., y Renard, J.-B., Légendes urbaines. Rumeurs d'aujourd'hui, París, 1992, 7-16.

${ }^{75} \mathrm{Si}$ se generó en relación con el desastre de Alarcos (1195), estaríamos ante un «rumor sumergible», es decir, aquél que resurge cuando se repiten unas coyunturas similares a las originales, Allport-Postman, 187.

${ }_{76}$ «La ansiedad y el miedo son [los] estímulos ocultos» del rumor, Allport-Postman, 18. En este sentido no hay que olvidar que en 1212 todo el mundo sabía que los reyes de León y Navarra eran aliados del imperio almohade frente al bloque formado por Castilla-Aragón. 
Otro elemento clave del rumor del «desafío del Miramamolín» es la percepción de un enfrentamiento a gran escala entre cristianos y musulmanes en la Península Ibérica. Desde 1200 los reinos hispanos avanzaron hacia una colaboración militar cada vez más factible y mejor considerada frente a la presión almohade. Esta aspiración fue propiciada por las severas reacciones a la derrota de Alarcos (por parte de papas, clérigos y trovadores), el lento agotamiento de las inútiles luchas entre los reyes cristianos, el esfuerzo pacificador de la diplomacia pontificia, el interés de la corona de Aragón y, en última instancia, por la labor catalizadora de personajes imbuidos del espíritu cruzado como el infante Fernando de Castilla o Rodrigo Ximénez de Rada, arzobispo de Toledo desde 1208. A todo ello se sumó el clima de guerra santa que vivía el Languedoc desde el inicio de la Cruzada Albigense (1209), una empresa bélico-religiosa, cuyo eco llegaba intensamente a la Península.

En este contexto se produjo la ruptura de hostilidades y la ofensiva almohade sobre Salvatierra, convento mayor de los caballeros de Calatrava, vinculados a la Orden del Císter. La resistencia de los monjes-guerreros se prolongó durante cincuenta y un días, suscitando la atención de numerosos círculos eclesiástico-religiosos en gran parte de Europa. La conmoción por la conquista de Salvatierra se difundió rápidamente y resucitó el temor a una nueva ofensiva general musulmana, sensación ajustada a una peligrosa coyuntura militar de Castilla que tanto Alfonso VIII como los cistercienses supieron explotar convenientemente en una Europa ya «mentalizada» para el gran choque contra el Imperio Almohade ${ }^{77}$.

El rumor del «desafío del Miramamolín» debió ser, por tanto, consecuencia y también acicate de la crisis bélico-religiosa creada por la ofensiva almohade, la necesidad de una reacción militar cristiana, la guerra del Languedoc y la propaganda de cruzada atizada por las cortes de Castilla y Aragón, la Orden del Císter, el papado y los trovadores.

En este clima las supuestas amenazas del Miramamolín almohade tomaron forma a partir de la combinación de elementos extraídos de circunstancias reales del momento - «casi todo rumor parte de una percepción de cierta clase»- y de concepciones ideológico-mentales de la época ${ }^{78}$. Al-

77 El impacto emocional causado por la pérdida de Salvatierra lo reflejan Jiménez de Rada (VII, xxxv, 305, 12-18) y la Crónica Latina (24-25); véanse también las reflexiones de Lo$\max , 38-39$. Conquistada Salvatierra, los almohades estaban en condiciones de atacar el valle del Tajo y Toledo partiendo de Calatrava la Vieja, capital y base militar de la submeseta sur.

78 Allport-Postman, 164. 
gunas de estas circunstancias y concepciones fueron: la conciencia del potencial militar musulmán; la categoría del Miramamolín como señor de todo el Islam occidental —su título de comendador de los creyentes suele ser traducido como rey de reyes-; el gran volumen del ejército almohade - dato real-; la desmedida soberbia del califa almohade - tópico también verosímil-; el temor a un ataque musulmán de graves repercusiones para toda Europa - un viejo proyecto almohade — , y la necesidad de frenar esta amenaza mediante una gran batalla campal, juicio de Dios concebido por la mentalidad bélica plenomedieval como un último recurso sancionador de la virtud del vencedor y su causa o su religión ${ }^{79}$.

Desde el punto de vista psicológico, la crisis de 1212 se ajusta con precisión a la triple dinámica que conduce a la creación del rumor: descargar la tensión emocional inmediata proporcionando una salida verbal que produzca alivio; ofrecer una amplia interpretación de una compleja coyuntura circundante, y jugar un importante papel en el esfuerzo intelectual dirigido a hacer comprensible el ambiente que se está viviendo ${ }^{80}$.

Esta última característica, la necesidad de encontrar «una razón plausible» que dé explicación a «una situación confusa», tendría su mejor exponente en la compleja versión del «desafío del Miramamolín» que Berlioz denomina «complot de l'étranger»: la peligrosa situación de los cristianos meridionales a principios del siglo XIII, inmersos en dos arriesgados enfrentamientos simultáneos contra los más importantes adversarios de la Cristiandad — musulmanes y herejes-, motivó que autores como Cesáreo de Heisterbach y otros muchos contemporáneos vieran en la alianza «natural» de los enemigos de Dios la explicación más razonable a la convulsionada coyuntura político-militar 1195-1215, en la que los católicos se enfrentaron decisivamente a sus más poderosos enemigos.

Hecho histórico o rumor espontáneo, el «desafío del Miramamolín» fue aceptado como cierto en gran parte de Europa durante los prolegómenos de la Cruzada de Las Navas de Tolosa. Su funcionalidad como elemento pro-

79 Aun con exageraciones, los ejércitos almohades solían ser muy grandes, Viguera, 244 y ss. La exageración de cifras es típica del rumor, pues «es muy raro que las cantidades disminuyan, mientras se difunde el rumor», Allport-Postman, 168. Sobre cuestiones numéricas e ideología en esta batalla, véase mi trabajo «La muerte del enemigo en el pleno Medievo: cifras e ideología (El modelo de Las Navas de Tolosa), en Hispania. Sobre la concepción ideológico-litúrgica de la batalla, véase Duby, G., Le dimanche de Bouvines, Sarthe, 1985, esp. pp. 191-192. para el caso de Las Navas, véase mi trabajo, «Dimensiones religiosas y liturgia de la batalla plenomedieval...», en $X X$ Siglos.

80 Allport-Postman, 20. 
pagandístico residió en presentar la batalla anunciada para el verano de 1212 como el gran enfrentamiento de dos «mundos»: el Islam del Miramamolín almohade y la Cristiandad de los adoradores de la $\mathrm{Cruz}^{81}$. Entre los musulmanes también fueron percibidas las excepcionales dimensiones de la campaña de Hisn al-`Iqāb, pero no podemos saber si el «desafío» llegó a conocerse ni si pudo actuar como dinamizador de la guerra contra los cristianos.

Desde el punto de vista historiográfico, el espectacular desenlace de la batalla de Las Navas de Tolosa convirtió el rumor del «desafío del Miramamolín» en elemento asociado a su recuerdo histórico, lo que explica su prolongación en el tiempo y su progresivo enriquecimiento en algunas originales fuentes europeas ${ }^{82}$. En relación con esta difusión, sólo las cartas de Inocencio III y Arnaldo Amalarico, la Crónica Latina, los Anales Toledanos I y quizá la cansó de Gavaudán se enmarcan en torno a los hechos, mientras que todas las demás fuentes bebieron de noticias posteriores a la Cruzada de 1212 procedentes, en principio, de aquéllas.

En todas las versiones el «desafío» representa una contundente demostración de la victoria de los cristianos sobre un poderoso enemigo infiel dispuesto a destruir «toda la cristiandad». También en todas ellas la soberbia es el pecado castigado por la virtud de nuestro Señor Jesucristo mediante una contundente derrota en batalla campal, la máxima expresión del Juicio de $\operatorname{Dios}^{83}$. La elaboración de relatos complejos a partir de las noticias más próximas a los acontecimientos tuvo, por tanto y en definitiva, una intención aleccionadora de carácter ideológico-historiográfico.

81 Sobre la cuestión ideológica, véase mi trabajo en Heresis.

82 Respecto a las noticias orales como fuente historiográfica, B. Guénée afirma que el historiador medieval «il sait que la mémoire populaire n'est guère fidèle... Mais quitte à être prudent, il n'entend pas s'en priver, car souvent, après tout, ce qui est dit n'est pas écrit mais aurait pu l'être, permet seul de combler des sources écrites indigentes, et, comme le disait saint Augustin, ce que rapporte le rumeur publique ne doit être ni entièrement accepté ni tout à fait rejété». Es más, este autor afirma que entre los historiadores protagonistas de la gran historiografía de los siglos XII y XIII, «l'utilisation de ces sources orales a été une décision délibérée de leur erudition» (aunque se refiere sobre todo a cantares de gesta y otros relatos populares, esta conclusión puede ser válida para noticias orales y populares como la que nos ocupa). Véase Guénée, B., Histoire et culture historique dans l'Occident médiéval, París, 1980, 79 y $82-84$

83 Crónica Latina, 33, 26-27. 
Supuesto proceso de difusión del «desafío del Miramamolín» o de algunos de sus elementos principales

Fuentes almohades

— Ibn Șāḥib al-Ṣalā (febrero 1163).

\section{Fuentes europeas no hispanas}

- Folquet de Marsella (julio 1195-26 de abril 1196).

- Gavaudan (¿1195-1212?).

- Inocencio III (5 abril 1212).

- Combatientes (primavera 1211-agosto 1212).

- Arnaldo Amalarico (11 agosto 1212)* Capítulo General del Císter (13 septiembre 1212). Monasterios cistercienses de toda Europa.

Cesáreo de Heisterbach (h. 1219-23) $\rightarrow$ Anales de Colonia Crónicas francesas $\rightarrow$ Alberico (h. 1241). ¿Crónicas italianas?

- ¿Guilhem Aneliers de Tolosa (h. 1277)?

\section{Fuentes hispanas}

- Combatientes (primavera 1211-agosto 1212).

- Arnaldo Amalarico (11 agosto 1212).

- Anales Toledanos I $\rightarrow$ Crónica Latina (1236) $\rightarrow$ Lucas de Tuy (1236) ¿Crónica de Bernat Desclot (h. 1285-1288)? ¿Crónicas alfonsíes (h. 1270-1295)?

\section{RESUMEN}

Numerosas fuentes de toda Europa afirmaron que antes de la batalla de Las Navas de Tolosa (16 julio 1212) el Miramamolín almohade al-Nāṣir (1199-1213) pro-

* Arnaldo Amalarico era, según algunas fuentes coetáneas, de origen hispano, pero lo consideramos una fuente «ultramontana» por su condición de legado papal en la cruzada albigense, arzobispo de Narbona y ex abad del Císter. 
clamó su deseo de combatir a toda la cristiandad en una gran batalla campal. Asociada al recuerdo de la gran victoria cristiana, la noticia del «desafío del Miramamolín» apareció en la cronística hispánica y europea del siglo XIII en diferentes versiones y experimentó un progresivo enriquecimiento. Ello permite observar un hecho singular y relevante en la historiografía medieval: la conversión de una noticia incierta en un hecho histórico y hasta documentado debido a su carácter excepcional o aleccionador. El análisis de su cronología durante el crítico período 1195-1212 y de su posible origen «histórico» permiten considerar el «desafío del Miramamolín» un rumor de gran difusión espacio-temporal cargado de intencionalidad ideológicopropagandística y enmarcado en el contexto de la crisis bélico-religiosa que envolvió la cruzada hispánica de Las Navas de Tolosa. Hecho real o supuesto, este episodio es interesante porque fue considerado cierto por muchos de los contemporáneos, lo que explica su posterior importancia historiográfica. Por la misma razón es posible observar en él buena parte de los elementos ideológicos y psicológicos que formaban parte de la mentalidad bélica de la cristiandad de principios del siglo XIII.

\begin{abstract}
Numerous European sources have asserted that before the battle of Las Navas de Tolosa (1212, July 16) the Almohade Miramamolin al-Nāșir (1199-1213) proclaimed his wish to fight against all Christendom in a great pitched battle. Joined to the memory of the great Christian victory, the notice of the «Miramamolin's challenge» appeared in different versions and experienced a progressive enrichment. That allows us to observe a singular and outstanding feature in medieval historiography: the conversion of a uncertain fact into a historical and even well-documented event owing to its unusual or instructive nature. The analysis of its chronology during the critical period 1195-1212 and of its possible «historical» origin allows us to judge the «Miramamolin's challenge» like a rumor of great geographic and temporal diffusion full of ideological and propagandistic intention and framed in the context of military and religious crisis that involved the Spanish Crusade of Las Navas de Tolosa. Real or suppossed event, this episode is interesting because it was believed true by many contemporaries. It explains its subsequent historiographical importance. For the same reason it is possible to observe through its analysis many of the ideological and psychological elements that conformed the warlike mentality of Christendom at the beginning of the 13th Century.
\end{abstract}

